\title{
CHILD ABUSE AND NEGLECT: MANDATORY REPORTING AND THE LEGAL PROFESSION
}

\author{
VANESSA DEVERSON*
}

Child abuse and neglect affects approximately 42500 children in Australia each year. Parliaments in all Australian states and territories have introduced mandatory reporting into child protection legislation to protect vulnerable children by requiring certain individuals to report suspicions of abuse or neglect. However, lawyers are prevented from reporting because of the rules governing legal professional privilege and confidentiality. This article begins by examining the problem of child abuse and neglect in Australia and outlines the current legislative framework of mandatory reporting laws in Part II. Part III discusses the current rules governing lawyers and examines legal professional privilege and the duty of confidentiality. Part IV provides arguments for and against requiring lawyers to report suspected abuse and also considers the lawyer-client relationship and the special position of domestic violence victims. Part V offers recommendations for the proposed legislative reform. This article concludes that lawyers should be required to report child abuse and neglect.

\section{CONTENTS}

I Introduction 103

II Child Abuse and Neglect in Australia.... 104

A Mandatory Reporting Laws 106

III

Current Rules Governing Lawyers 108

A Legal Professional Privilege. 108

B Duty of Confidentiality. 111

IV It Is Necessary for Lawyers to Report 113

A Preserving the Lawyer-Client Relationship.... 115

B An Exception in Cases of Domestic Violence 116

V Recommendations for Legislators 119

A Problems with Vagueness in Other Jurisdictions 119

* LLB student, School of Law, University of South Australia. 
B The Proposed Amendment

\section{INTRODUCTION}

Every person has an inherent right to life and a fundamental right to bodily integrity. This right applies both to adults and to children. Article 6 of the Convention on the Rights of the Child states that signatory countries are to 'ensure to the maximum extent possible the survival and development' of children. ${ }^{1}$ However, currently each year in Australia approximately 42500 children experience abuse or neglect by a family member. ${ }^{2}$ In 2014-15, there were 320169 notifications $^{3}$ of child abuse or neglect received by state and territory government agencies in Australia and at the same time thousands of cases went unreported. ${ }^{4}$ Child abuse and neglect is clearly a substantial problem in Australia. In an effort to reduce the prevalence of abuse and neglect, and taking into account the often 'secretive' nature of abuse, parliaments in all Australian states and territories have enacted child protection legislation. This legislation requires certain individuals to report suspicions of child abuse or neglect. The professions who most commonly interact with children and families, like doctors and police officers, are required to report. No jurisdiction specifically requires lawyers to report their suspicions or knowledge of child abuse or neglect and lawyer-client privilege stops a lawyer from disclosing allegations of child abuse or neglect unless the client waives privilege. Professional ethics dictate that a lawyer must keep the client's information confidential. A report made without the client's consent would be breaching professional conduct rules.

Lawyers need to be able to report to protect vulnerable children. Children cannot protect themselves; that is why mandatory reporting legislation was

Convention on the Rights of the Child, opened for signature 20 November 1989, 1577 UNTS 3 (entered into force 2 September 1990) art 6.

2 Australian Institute of Health and Welfare, Child Protection Australia 2014-15, Child Welfare Series No 63 (2016) 19.

3 Ibid.

4 Act For Kids, Child Abuse and Neglect in Australia (2014) <https://www.actforkids.com.au/the-issue/>. 
enacted. This article argues that to protect children, lawyers should be mandated reporters. Part II of this article examines the problem of child abuse and neglect in Australia as well as the mandatory reporting laws currently operating. Part III examines the rules currently governing lawyers that prevent them from reporting; specifically, lawyer-client privilege and the duty of confidentiality. Part IV begins by discussing the arguments for and against requiring lawyers to report before moving on to consider the effects on the lawyer-client relationship and the special position of domestic violence victims. Part V offers recommendations for the proposed legislative reform and Part VI concludes that lawyers should be legally required to report child abuse and neglect.

\section{ChILd ABuse AND Neglect in Australia}

It has been just over 50 years since Henry Kempe and his colleagues brought the problem of child abuse into the public eye. ${ }^{5}$ The seemingly indefinable phenomenon of children with unexplainable injuries was finally defined as 'battered child syndrome' - a term used to 'characterize a clinical condition in children who [had] received serious physical abuse, generally from a parent or foster parent. ${ }^{6}$ Kempe et al suggested that the 'syndrome' should be suspected where there is 'evidence of fracture of any bone, subdural hematoma, failure to thrive, soft tissue swellings or skin bruising [or] in any child who dies suddenly. ${ }^{7}$ Today, as a result of increased public awareness and changing social values, there is a much broader definition of abuse.

The Australian Institute of Family Studies recognises abuse as including physical, sexual and emotional harm as well as neglect and exposure to family violence. ${ }^{8}$ Each state and territory has included in their legislation either specific definitions of abuse and neglect or descriptions that identify the circumstances where a child is in need of protection. For example, s 6 of the Child Protection Act 1993 (SA) defines abuse or neglect to mean:

(a) sexual abuse of the child; or

(b) physical or emotional abuse of the child, or neglect of the child, to the extent that-

5 Henry Kempe et al, 'The Battered-Child Syndrome’ (1985) 9 Child Abuse and Neglect 143.

6 Ibid.

Ibid.

8 Australian Institute of Family Studies, What is Child Abuse and Neglect? (September 2015) $<$ https://aifs.gov.au/cfca/publications/what-child-abuse-and-neglect>. 
(i) the child has suffered, or is likely to suffer, physical or psychological injury detrimental to the child's wellbeing; or

(ii) the child's physical or psychological development is in jeopardy.

The Children and Young Persons (Care and Protection) Act 1998 (NSW) more extensively states in $\mathrm{s} 23$ that a child or young person is at risk of significant harm when they are exposed to any of a number of circumstances, which include physical harm, sexual abuse and psychological harm. ${ }^{9}$ They also include circumstances where the child's parents are unable or unwilling to arrange medical care or education, ${ }^{10}$ or where the child is exposed to domestic violence. $^{11}$

What society was so reluctant to accept 50 years ago is now, sadly, acknowledged as being common. News stories of child abuse and neglect have brought public awareness to the significance of the problem. ${ }^{12}$ In 2014-15, 'there were 320169 notifications involving around 208100 children, a rate of 39.2 per 1000 children in Australia'. ${ }^{13}$ The Australian Institute of Health and Welfare noted that: 'Of the notifications, 48 per cent (137 585) were investigated, with 56400 substantiations'.${ }^{14}$ However, 'nationally, only 0.3 per cent of notifications came directly from the child involved.' ${ }^{15}$ Because it often requires someone outside the family unit to report the suspected abuse or neglect, Australian parliaments have created child protection laws in each state

9 Children and Young Persons (Care and Protection) Act 1998 (NSW) s 23(1)(c) 'has been, or is at risk of being, physically or sexually abused or ill-treated' and s 23(1)(e) 'is living in a household where there have been incidents of domestic violence and, as a consequence, the child or young person is at risk of serious physical or psychological harm'.

10 Ibid sub-ss 1(b), (b1), 1(e).

11 Ibid sub-s 1(e).

12 See: Joanna Menagh, 'Child Molester who Targeted Daughters and Children's Friends over 20 Years Jailed', ABC News (online), 15 April 2016, <http://www.abc.net.au/news/2016-0415/child-molester-who-assaulted-daughters-jailed/7330476>; Candice Prosser, 'Young SA Mother and her Partner Found Guilty of Criminal Neglect of Two-Year-Old Girl', ABC News (online), 7 April 2016, <http://www.abc.net.au/news/2016-04-07/young-sa-mother-partnerfound-guilty-criminal-neglect-2yo-girl/7308636>; Joanna Menagh, 'Father Charged over Baby's Death Remanded to Psychiatric Facility', ABC News (online), 27 April 2016, $<$ http://www.abc.net.au/news/2016-04-27/father-charged-over-baby-death-remanded-topsychiatric-facility/7364632>.

13 Australian Institute of Health and Welfare, above n 2, 19.

14 Ibid.

15 Ibid 21. 
and territory which require certain individuals to report suspicions of child abuse and neglect. They are commonly called 'mandatory reporting laws'.

\section{A Mandatory Reporting Laws}

Australian parliaments began enacting child protection legislation in 1970 . There have been many developments since then and the legislation continues to evolve today. Each Australian state and territory has enacted legislation requiring certain professions and individuals to report suspicions of child abuse. ${ }^{16}$ Common to each Act is:

- a definition of which persons must report;

- the state of mind required of a reporter;

- the types and extent of abuse that needs to be reported;

- whether past, present or future abuse needs to be reported;

- $\quad$ penalties for failing to report;

- confidentiality and immunity protection for the reporter; and

- the details a report requires and when and to whom it must be reported. ${ }^{17}$

There are also differences in the legislation across each jurisdiction. For example, states differ over which persons are required to report. Some states list the required professionals, whereas in the Northern Territory all persons are mandated reporters. ${ }^{18}$ In 2009 the Northern Territory amended its child protection legislation to require all persons to report child abuse and neglect and to create an offence for failing to report. Section 26 (3) of the Care and Protection of Children Act 2007 (NT) ('CAPCA') states that: 'This section has effect despite any other provision in this Act or another law of the Territory'. This includes the common law. ${ }^{19}$ Furthermore, s 27 of the CAPCA states that:

16 See: Children and Young People Act 2008 (ACT) s 356; Children and Young Persons (Care and Protection) Act 1998 (NSW) ss 23, 27; Care and Protection of Children Act 2007 (NT) ss 15-16, 26; Child Protection Act 1999 (Qld) ss 13E-13J; Children's Protection Act 1993 (SA) ss 6, 10, 11; Children, Young Persons and Their Families Act 1997 (Tas) ss 3-4, 14; Children, Youth and Families Act 2005 (Vic) ss 182, 184; Children and Community Services Act 2004 (WA) ss 124A-H; Family Law Act 1975 (Cth) ss 4, 67ZA.

17 Ben Matthews and Kerryann Walsh, Mandatory Reporting Laws (May 2014) Australian Institute of Family Studies <https://aifs.gov.au/publications/families-policy-and-law/14mandatory-reporting-laws $>$ pdf, 134.

18 See Australian Institute of Family Studies, Mandatory Reporting of Child Abuse and Neglect (May 2016) <https://aifs.gov.au/cfca/publications/mandatory-reporting-child-abuse-andneglect> for a comparison of mandatory reporting legislation across Australian jurisdictions.

19 Barbara Bradshaw, Guideline for Legal Practitioners: Mandatory Reporting Laws, Law $\begin{array}{lll}\text { Society Northern } & \text { Territory }\end{array}$ 
'A person acting in good faith in making a report under section 26 is not ... in breach of any professional code of conduct'. The correct interpretation of the reference in this section to 'any professional code of conduct' has not been decided by a court; however, the Law Society of the Northern Territory suggests in the 2009 Guidelines for Legal Practitioners that the provision displaces both the confidentiality requirements and client legal privilege and so would not allow a lawyer to avoid making a report. ${ }^{20}$ The conclusions in this article do not, therefore, apply to the Northern Territory, apart from the need to make it clear that the legislation overrules legal privilege and confidentiality.

Two of the main arguments against mandatory reporting focus firstly on the risk of increasing the number of unsubstantiated reports and secondly on the risk that these reports would generate extra workload for child protection and welfare services. ${ }^{21}$ Despite these problems with mandatory reporting, it is clear that these rules do increase the number of reports and the number of substantiated reports, and consequently, they protect children who could otherwise have gone unnoticed by authorities. The benefits and effectiveness of mandatory reporting, coupled with the fact that child abuse and neglect continues to be a major issue, leads to the suggestion that further reforms to the mandatory reporting legislation are necessary. Benjamin Mathews and Maureen Kenny, in analysing mandatory reporting legislation, suggest a number of questions for legislative reform: ${ }^{22}$

1. Are mandated reporters limited to selected occupations (and if so which), or is the reporting duty imposed on all citizens;

2. What types of abuse and neglect are required to be reported;

3. What level of suspicion is required to activate the reporting duty (and how is this expressed);

4. Within the three major types of abuse, are reports required of suspected abuse from all sources or from selected perpetrators such as parents and caregivers;

5. Are any 'new' types of abuse required to be reported, and if so which;

2009).<http://www.lawsocietynt.asn.au/images/stories/Mandatory_Reporting_and_Privilege _Guideline.pdf> 6 [19], citing s 17 of the Interpretation Act 1978 (NT), which defines 'law of the territory'.

$20 \quad$ Ibid 6.

21 Benjamin Mathews and Donald Boss, 'Mandated Reporting Is Still a Policy with Reason: Empirical Evidence and Philosophical Grounds' (2008) 32(5) Child Abuse and Neglect 5112.

22 Ben Mathews and Maureen Kenny, 'Mandatory Reporting Legislation in the United States, Canada and Australia: A Cross-Jurisdictional Review of Key Features, Differences and Issues' (2008) 13(1) Child Maltreatment 50, 62. 
6. Are the types of abuse that require reporting defined to indicate the extent of harm required to be suspected (if so, how), or does the reporting obligation apply to any occurrence of the abuse; and

7. Are reports required only of past or present abuse, or are reports also required of suspected risk of future abuse (if so, under what circumstances? ? $^{23}$

This article addresses the first of these questions and argues that members of the legal profession should be required to report by law.

\section{CURRENT RULES GOVERNING LAWYERS}

When a lawyer forms an opinion that a child is potentially being abused or neglected, they are morally obliged to take action to help the child. As citizens we all have a duty to protect the vulnerable. However, because of lawyer-client privilege and professional ethics, lawyers are bound or obliged respectively, to keep their suspicions to themselves and they are unable to make a report. If lawyers breach privilege or confidentiality their actions could 'constitut[e] unsatisfactory professional conduct or professional misconduct and may give rise to disciplinary action'. ${ }^{24}$ This creates an irreconcilable clash between their professional duties to their client and their moral obligation to the child.

\section{A Legal Professional Privilege}

Legal professional privilege is a rule of substantive law. ${ }^{25}$ Privilege:

may be availed of by a person to resist the giving of information or of the production of documents which would reveal communications between a client and [their] lawyer made for the dominant purpose of giving or obtaining legal advice or the provision of legal services. ${ }^{26}$

So, communications (including documents) made by a client to their lawyer, will be protected from being disclosed or used as evidence if the

23 Ibid.

24 Law Society of South Australia, Australian Solicitors' Conduct Rules (at 1 July 2015) r 2.3. Penalties could result from disciplinary action and may include reprimands, costs or an undertaking not to apply for a practising certificate.

25 Attorney-General (NT) v Maurice (1986) 161 CLR 475, 490 (Deane J); The Daniels Corporation International Pty Ltd v Australian Competition and Consumer Commission (2002) 213 CLR 543, 552 (Gleeson CJ, Gaudron, Gummow and Hayne JJ).

26 The Daniels Corporation International Pty Ltd v Australian Competition and Consumer Commission (2002) 213 CLR 543, 552 (Gleeson CJ, Gaudron, Gummow and Hayne JJ). 
communications or documents were made while getting legal advice or being represented.

The High Court has recognised legal professional privilege as a right. ${ }^{27}$ The Court stated in The Daniels Corporation International Pty Ltd v Australian Competition and Consumer Commission that privilege was 'an important common law right or, perhaps, more accurately, an important common law immunity. ${ }^{28}$ Courts have made it clear that, due to the fundamental nature of the right to client legal privilege, they will not interpret legislation to have abrogated privilege 'in the absence of clear words or a necessary implication to that effect. ${ }^{29}$ As Kirby J explained: 'Baker ${ }^{30}$ lays great emphasis upon the importance of legal professional privilege, holding that very clear, indeed unmistakeable, provisions of legislation will be needed to deprive a person, otherwise entitled, of such privilege. ${ }^{31}$ This reflects the importance with which the courts regard legal professional privilege and their reluctance to infringe upon the right.

Baker v Campbell ${ }^{32}$ outlines the traditional justifications for legal professional privilege. Chief Justice Gibbs explained that open communication between lawyer and client is necessary for the 'administration of justice' ${ }^{33}$ and Wilson $\mathrm{J}$ also observed that 'the adequate protection according to law of the privacy and liberty of the individual is an essential mark of a free society and ... [the] privilege ... is an important element in that protection.' ${ }^{34}$ Privilege is fundamental to the lawyer-client relationship and helps to 'promot[e] free disclosure between clients and lawyers, to enable lawyers to give proper advice

27 Baker v Campbell (1983) 153 CLR 52; The Daniels Corporation International Pty Ltd v Australian Competition and Consumer Commission (2002) 213 CLR 543, 553 (Gleeson CJ, Gaudron, Gummow and Hayne JJ).

28 The Daniels Corporation International Pty Ltd v Australian Competition and Consumer Commission (2002) 213 CLR 543, 553 (Gleeson CJ, Gaudron, Gummow and Hayne JJ).

29 Ibid.

$30 \quad$ Baker v Campbell (1983) 153 CLR 52.

31 The Daniels Corporation International Pty Ltd v Australian Competition and Consumer Commission (2002) 213 CLR 543, 570 (Kirby J) citing Baker v Campbell (1983) 153 CLR 52.

32 (1983) 153 CLR 52.

33 Ibid 66 (Gibbs CJ), citing Stephen J in Smorgon v Australia and New Zealand Banking Group Ltd (1976) 134 CLR, 488.

34 Bakerv Campbell (1983) 153 CLR 52, 95. 
and representation to their clients. ${ }^{35}$ When lawyers have all the information, they are better able to give the most appropriate advice. In the general case, information shared between lawyer and client should remain privileged; however, in the case of suspected child abuse or neglect, the child's right to safety should outweigh the client's right to privilege. Despite the fundamental nature of the privilege it should not protect suspicions of child abuse and neglect.

Any privilege 'reflects a societal judgement that the need for confidentiality outweighs the need for disclosure. ${ }^{36}$ Equally, however, the justifications for privilege are outweighed by the moral duty to protect children. It is clear that over recent years society's values have changed and there is now a stronger focus on child protection. This is evidenced by the Australian Government's introduction of the 'Protecting Children is Everyone's Business: National Framework for Protecting Australia's Children 2009-2020' which aims to 'ensure that there is a substantial and sustained reduction in child abuse and neglect in Australia.' ${ }^{37}$ The legislative reforms already made in the areas of mandatory reporting laws, domestic violence and children's rights also reflect society's changing values. These initiatives suggest that the public interest in confidentiality is now outweighed by the public interest in disclosure for the protection of children. Consequently, privilege should not be available in instances of child abuse or neglect and lawyers should be able to, and required to, report suspected abuse.

The fundamental nature of privilege is not in question, and a total abrogation of legal professional privilege is neither required nor desired. However, in the limited and specific situation where a lawyer suspects that a child is being abused or neglected, they should report their suspicion and they should not be prevented by lawyer-client privilege. Like others who are mandated reporters, lawyers would not be required to testify against their client, and likewise, they could remain anonymous under the child protection legislation in every

35 Australian Law Reform Commission, Uniform Evidence Law, Report No 102 (2006) [14.44].

36 Payton v New Jersey Turnpike Authority, 148 NJ 524 (1997), 540 (Handler J).

37 Department of Social Services, National Framework for Protecting Australia's Children 2009-2020 - Annual Report 2012-13 (October 2014)

<https://www.dss.gov.au/sites/default/files/documents/10_2014/nfpac_annualrpt201213.pdf $>$. 
jurisdiction. ${ }^{38}$ Only the information required by the child protection legislation need be disclosed, and all other communications should remain privileged.

\section{B Duty of Confidentiality}

Confidentiality is similar to privilege, but it is founded in contractual obligations and is a professional conduct rule, rather than a common law right. ${ }^{39} \mathrm{~A}$ duty of confidentiality applies to all communications between a lawyer and client apart from a few exceptions. ${ }^{40}$ There are professional penalties if the solicitor breaks this confidentiality and disciplinary action is taken. Every jurisdiction has rules of professional conduct for solicitors and all of those rules contain a provision on confidentiality. For example, the Australian Solicitors' Conduct Rules set out the rule on confidentiality in $\mathrm{r} 9.1$ which states that '[a] solicitor must not disclose any information which is confidential to a client and acquired by the solicitor during the client's engagement.' Across each jurisdiction an exception permits a breach of confidentiality where the solicitor is 'permitted or is compelled by law to disclose. ${ }^{41}$ For this reason, if mandatory reporting legislation were to be extended to cover lawyers, they would not be breaching professional ethical standards because they would be covered by this exception and would be compelled by law to report.

Adrienne Lockie argues that '[r] equiring attorneys to report child abuse tramples upon the value of confidentiality, which is fundamental to the attorney-client relationship.' 42 She maintains that the lawyer-client relationship 'relies on confidentiality to a greater extent than do other professions' and is 'unique [in that it] relies upon confidentiality to carry out the purposes of representation.' ${ }^{43}$ To show that there are professionals who also need to maintain confidentiality but who are nevertheless able to perform

38 See, eg, Australian Institute of Family Studies, Mandatory Reporting of Child Abuse and Neglect (May 2016) <https://aifs.gov.au/cfca/publications/mandatory-reporting-child-abuseand-neglect> which outlines the protection given to reporters in all jurisdictions.

39 A breach of the duty of confidentiality is actionable in contract and also in tort.

40 Law Society of South Australia, Australian Solicitors' Conduct Rules (15 July 2015) r 9.

41 Ibid $r$ 9.2.2. Other relevant exceptions include: $r$ 9.2.4 where 'the solicitor discloses the information for the sole purpose of avoiding the probable commission of a serious criminal offence'; and $\mathrm{r}$ 9.2.5 where 'the solicitor discloses the information for the purpose of preventing imminent serious physical harm to the client or to another person'.

42 Adrienne Lockie, 'Salt in the Wounds: Why Attorneys Should Not Be Mandated Reporters of Child Abuse’ (2006) 36 New Mexico Law Review 125, 140.

43 Ibid 131 
their job despite having to report abuse, Lockie points out that a doctor is still able to set a broken leg and report abuse and that a priest is still able to provide absolution and report the abuse. ${ }^{44}$ However, there are other professions, for example psychologists and psychiatrists, who 'rely on confidentiality' to carry out their job but who are also mandated reporters. These professions require confidentiality to build trust and to encourage their patients to confide in them and they are also mandated reporters. In a study by Ann Knowles and Marilyn McMahon

[t]wo hundred and fifty-six members of the Australian public were surveyed regarding situations in which a psychologist might breach confidentiality... While respondents supported confidentiality within the psychotherapeutic relationship, they clearly distinguished situations in which ... disclosure could appropriately occur. Disclosure was expected and preferred when a client revealed child abuse. ${ }^{45}$

The same approach should be applied to the duty of confidentiality expected of a lawyer.

When mandatory reporting legislation was introduced in 1977 in NSW, some opposed it because it would interfere with doctor-patient confidentiality. ${ }^{46}$ The Minister for Youth and Community Services, when presenting the second reading speech for the proposed legislation, addressed this argument. He noted that as a general rule, information should remain confidential, but highlighted the fact that 'the child patient is an infant who cannot protest, and, even if older, the child may be unable to articulate his protest. However, he has fundamental rights and it is those rights that we are trying to protect. ${ }^{47} \mathrm{He}$ commented that where a doctor is bound by doctor-patient confidentiality but a child is likely being abused 'it is the welfare of the child that must be the paramount consideration. ${ }^{48}$ The same arguments that were applied to doctorpatient confidentiality in 1977 can be applied to lawyer-client confidentiality today. As a general rule, lawyer-client communication should remain protected by confidentiality and privilege. However, when a child is potentially being

44 Ibid, text in footnote 36.

45 Ann Knowles and Marilyn McMahon, 'Expectations and Preferences Regarding Confidentiality in the Psychologist-Client Relationship' (1995) 30(3) Australian Psychologist 175. Disclosure was also expected and preferred in cases of murder (planned or confessed), suicide plans or treason.

46 New South Wales, Parliamentary Debates, Legislative Assembly, 2 March 1977, 4707 (Rex Jackson).

47 Ibid.

48 Ibid 
abused and a conflict of interest arises, the child's welfare must prevail. The effects of a report on the relationship between a lawyer and their client will be further discussed in Part IV.

\section{IT IS NECESSARY FOR LAWYERS TO REPORT}

It has been suggested that mothers will often make false allegations of child abuse or violence against fathers as a strategy in Family Court proceedings. ${ }^{49}$ However, evidence tends to show that this is incorrect and Professor Freda Briggs, a leading scholar and advocate for child protection, argues that the opposite is now occurring and suggests that mothers are more likely to supress such allegations rather than invent false ones. ${ }^{50}$ Professor Briggs comments that, in cases where the father has sexually abused the child, the statistics show that if the fathers ask in the Family Court for the child to live with them 'the chances are high they will succeed' because: ${ }^{51}$

Child sex offenders are masters of manipulation. They not only groom the child, they groom all those responsible for the child's safety. The labelling of the mother as mad or bad might mean that the abuser groomed and charmed the police, social workers and even the judge.

Professor Briggs has said that as a result, 'lawyers and Women's Legal Services are said to be advising mothers not to disclose child abuse or domestic violence. ${ }^{52}$ This is to avoid accusations of lying or coaching their children, which will reflect badly on them in the court process. ${ }^{53}$ This exposes flaws in the Family Court system that are beyond the scope of this article. However, it is clear that there are scenarios where children are possibly being abused and aside from the parent, the victim and the abuser, only a lawyer has this

49 Janet Johnston et al, 'Allegations and Substantiations of Abuse in Custody-Disputing Families’ (2005) 43(2) Family Court Review 283.

50 Freda Briggs, 'Only a Small Number of Parents Make False Claims of Child Abuse' The Australian (online), June 30 2014, <http://www.theaustralian.com.au/opinion/letters/only-asmall-number-of-parents-make-false-claims-of-child-abuse/newsstory/2c02d4837694481ad12453ef5cec56b2>.

51 Freda Briggs, Are Mothers and Children Being Silenced in the Family Court? (19 December 2014) Mom Network <http://momnetwork.dk/gb/are-mothers-and-children-being-silencedin-the-family-court/>. It is acknowledged that there are cases where it will be the mother who is the abuser and the same conclusions would apply.

52 Ibid.

53 Ibid. 
information. The lawyer needs to be able to report the abuse, and should be required to.

In the Family Court process, the two parents' interests are represented by their lawyers and each client is able to rely on privilege and confidentiality. Both privilege and confidentiality are fundamental to the lawyer-client relationship and in most instances they are beneficial both to the client and to the public interest in resolving disputes. However, when children are involved, privilege and confidentiality have to be balanced against the rights of the child and we must side in favour of protecting children. If anyone makes an allegation of abuse, the Family Court will appoint an independent children's lawyer and the allegations will be investigated. ${ }^{54}$ However, if one parent suspects or has knowledge of abuse but decides not to raise it as a strategy, albeit a sad one, the children's interests are not being protected. If the parent's lawyer has this information, they should be required to report it. The lawyer has a duty to their client but ultimately their duty is to the court. Under the Family Law Act the Court has to ensure that the best interests of the child are met. ${ }^{55}$ Failing to investigate abuse allegations cannot be in the best interests of the child. Children are vulnerable and cannot protect themselves; this is why parliaments in Australia have developed mandatory reporting legislation. A lawyer's duty to their client should not outweigh our duty to protect children. The focus has to be on the protection of the vulnerable. We need to protect those who are unable to protect themselves.

Beyond the arguments based on confidentiality and privilege, commentators provide two main reasons why lawyers should not be required to report. The first argument, discussed in Part A, claims that mandatory reporting will damage the lawyer-client relationship and the second, discussed in Part B argues that reporting will harm victims of domestic violence.

$54 \quad$ Family Law Act 1975 (Cth) s 68L. Note that the Family Court can also appoint an independent children's lawyer where: there is an intractable difference between the parents; the child is alienated from one or both parents; cultural or religious issues affect the child; the parent's conduct is anti-social and affects the child's welfare (includes family violence); either parent or the child have significant medical, psychiatric or psychological illness or personality disorder; neither parent appears suitable to care for the child; the child is mature and has strong views which would result in a complete denial of access to one parent; one parent wants to permanently relocate with the child; siblings will be separated; neither of the parents are represented or when it is an application regarding medical treatment for the child. See $\operatorname{Re} K$ (1994) FLC 92-461, 82-83 (Nicholson, Fogarty and Baker JJ).

55 Family Law Act 1975 (Cth) s 60B. 


\section{A Preserving the Lawyer-Client Relationship}

Lockie argues that requiring lawyers to report child abuse or neglect will harm the lawyer-client relationship and prevent open communication. ${ }^{56}$ She makes two objections: firstly, that merely explaining the reporting requirements to clients will detrimentally affect the relationship; and secondly, that mandatory reporting will force a lawyer to use the first meeting to explain complex and unclear laws rather than to build a relationship. ${ }^{57}$ Lockie is commenting on the current US mandatory reporting laws which, as Ellen Marrus explains, differ across states ${ }^{58}$ and which are unclear on the obligations of lawyers who report abuse. If the recommended Australian legislation was clear and lawyers knew what was expected and could clearly explain it to their clients, this obligation should not unduly affect the lawyer-client relationship.

Lockie argues that merely explaining the mandatory reporting requirements to clients would prevent the development of a 'meaningful' relationship. No jurisdiction in Australia has required lawyers to report except for the Northern Territory, where everyone is required to report. The Northern Territory Legal Aid Commission explains that information provided to a lawyer will be confidential unless situations of child abuse or neglect are disclosed. In that case "[the] lawyer will need to make a report to the Northern Territory Police or the Department of Children \& Families. ${ }^{59}$ Since the legislative changes in 2009 there have not been any reports of lawyer-client relationships being harmed by the requirement to report.

Furthermore, lawyers can breach confidentiality 'for the sole purpose of avoiding the probable commission of a serious criminal offence' or 'for the purpose of preventing imminent serious physical harm to the client or to another person. ${ }^{60}$ This exception exists because it is rational to expect that if, for example, a lawyer knows that their client is going to murder somebody, they need to do something to stop it. Likewise, if a lawyer knows that their client is going to commit a serious criminal offence, they need to do something to stop it. This is explained to a client before they sign the retainer and the

56 Lockie, above n 42, 125.

57 Ibid 140 .

58 Ellen Marrus, 'Please Keep My Secret: Child Abuse Reporting Statutes, Confidentiality and Juvenile Delinquency' (1998) 11(3) Georgetown Journal of Legal Ethics 509, 516-8.

59 Northern Territory Legal Aid Commission, Domestic Violence, Child Abuse and Neglect <http://familylawguide.ntlac.org.au/contents/domestic-violence-child-abuse-and-neglect/>.

60 Law Society of South Australia, Australian Solicitors' Conduct Rules (1 July 2015) rr 9.2.4, 9.2.5. 
client is made aware of situations where confidentiality will be breached. These exceptions demonstrate that it was deemed more important to protect society from serious harm and criminal offences than to preserve a 'meaningful' lawyer-client relationship. Nobody doubts that maintaining the lawyer-client relationship is less important than preventing 'imminent serious physical harm' or a 'serious criminal offence' and yet there is a reluctance to afford the same protection to vulnerable children. The same argument that supports these exceptions can rationally be applied to suspected cases of child abuse and neglect because protecting a child from abuse or neglect should be more important than preserving a 'meaningful' lawyer-client relationship.

In psychology, communication and an open relationship are essential. However, this profession is required to report and this is explained to a client in the first session. The interests of children and their potential abuse are more important than the protection of confidentiality and the fostering of a meaningful relationship between patient and psychologist. Breaching confidence leads to similar consequences for both psychologists and lawyers. Lockie argues that 'a client whose attorney reports child abuse may lose trust and confidence in the attorney' ${ }^{61}$ but it could be argued that this is the case for all professions. Trust is an important part of the relationship between psychologist and patient, yet we have decided children's rights are more important than protecting that relationship. It should be the same for the lawyer-client relationship. It is a double standard that cannot be rationally supported. The rationale behind mandatory reporting legislation was to ensure that those in the professions who come into contact with children or their parents should report the incidents to protect children who cannot report themselves. A lawyer who reports suspected child abuse could damage the lawyer-client relationship to some extent. Nonetheless, this potential for a damaged relationship should not be more important than protecting children from abuse and neglect. It is important to note that Lockie focuses primarily on the relationship between a lawyer and their client who is a victim of domestic violence. The above conclusions do not apply when representing a victim of domestic violence and this will be further discussed below.

\section{B An Exception in Cases of Domestic Violence}

Commentators like Lockie argue that legally requiring those in the legal profession to report will result in some victims of domestic violence being subjected to further harm. ${ }^{62}$ A report of suspected abuse will likely lead to an

61 Lockie, above n 42, 140.

62 Ibid 125 
investigation, possibly alerting the abuser that the victim is seeking assistance and potentially resulting in harm to the victim or children. ${ }^{63}$ Lockie argues that requiring lawyers to report discourages domestic violence victims from seeking help because they know that the lawyer will be required to make a report. ${ }^{64}$ Alerting the abuser that the victim is seeking legal assistance and discouraging victims from seeking help are clearly harmful to domestic violence victims and their children. Lockie argues that by 'requiring attorneys to report child abuse, society abandons domestic violence victims when they are most vulnerable. ${ }^{65}$

This is a substantial problem that cannot be overlooked. One in five women and one in twenty men have experienced domestic violence. ${ }^{66}$ In Australia, one woman dies every week as a result of family violence. ${ }^{67}$ Requiring lawyers to report suspected abuse when there is known domestic violence in the relationship could produce unintended detrimental results to the victim or potentially to the children as well. In 2014 the Victorian Government created a new criminal offence under s 327 of the Crimes Act 1958 (VIC), 'failure to disclose'. This imposed a duty on all adults to report information about child sexual offences to police. ${ }^{68}$ The new offence has an exception, however: a person will not be guilty of the offence if they have a reasonable excuse for not disclosing the information. ${ }^{69} \mathrm{~A}$ reasonable excuse includes a fear for safety. The rationale for this exception is 'to ensure that in creating this legal obligation, we do not put children and their families at even greater risk of harm, especially those who may be experiencing family violence. ${ }^{70}$ In the

63 Ibid 149.

64 Ibid 154

65 Ibid 149

66 Australian Bureau of Statistics, Personal Safety, Australia, 2012, cat no 4906.0 <http://www.abs.gov.au/ausstats/abs@.nsf/mf/4906.0>.

67 Andy Chan and Jason Payne, Homicide in Australia: 2008-09 to 2009-10 National Homicide Monitoring Program Annual Report, Australian Institute of Criminology (2013) <http://www.aic.gov.au/publications/current\%20series/mr/21-40/mr21.html>.

68 Crimes Act 1958 (VIC) s 327. See also Department of Justice, Failure to Disclose Offence (2014) Victoria State Government <http://www.justice.vic.gov.au/home/safer+communities/protecting+children+and+families/ failure+to+disclose+offence $>$. Note that lawyers would not report an offence if the information were privileged.

69 Crimes Act 1958 (VIC) s 327(2).

70 Department of Justice, Failure to Disclose Offence (2014) Victoria State Government <http://www.justice.vic.gov.au/home/safer+communities/protecting+children+and+families/ failure+to+disclose+offence $>$. 
Northern Territory, under s 26 of the Care and Protection of Children Act 2007, all persons must make a report if they believe a child is exposed to domestic violence. Also, under s 124A of the Domestic and Family Violence Act 2007 (NT), all persons must report domestic violence when they believe the victim's life is under threat. Under both Acts, the legislation provides an exception when a person has a reasonable excuse for not reporting. ${ }^{71} \mathrm{~A}$ reasonable excuse will include when a person believes that if they made the report as soon as reasonably practicable 'a serious or imminent threat to the life or safety of any person may result.' 72

Clearly, the issue of domestic violence and mandatory reporting is not going unnoticed by legislators. Jurisdictions have ensured in their mandatory reporting legislation that there are exceptions for instances of domestic violence. A similarly worded exception to those noted above could be included for cases of suspected child abuse or neglect. This would enable reporters to make judgement calls on whether it was safe to make a report when dealing with a domestic violence victim and suspected child abuse and neglect. A similarly worded provision that creates an exception in these cases could ensure the safety of domestic violence victims and their children while also providing an opportunity to make a report once it was safe to do so. It is important to note that

the rate of co-occurrence of Australian children experiencing physical abuse and being exposed to domestic violence, and experiencing sexual abuse and being exposed to domestic violence have been estimated at 55 per cent and 40 per cent respectively. ${ }^{73}$

Therefore, a report could not be put off indefinitely. The exception would not exempt lawyers from ever making a report but enable them to do so when it is safe. The rationale behind this exception is similar to that of the proposed amendment to make lawyers mandated reporters; to protect the vulnerable from harm. In the limited area of domestic violence situations where there would be a likely risk of serious harm, lawyers could rely on an exception to mandatory reporting.

71 Domestic and Family Violence Act 2007 (NT) s 124A(2); Care and Protection of Children Act 2007 (NT) s 26 (2).

72 Domestic and Family Violence Act 2007 (NT) s 124A(3)(c).

73 Kelly Richards, 'Children's Exposure to Domestic Violence in Australia'(2011) 419 Trends and Issues in Crime and Criminal Justice <https://search.informit.com.au/documentSummary;dn=673124328907485;res=IELHSS〉. 


\section{RECOMMENDATIONS FOR LEGISLATORS}

Lawyers in all Australian jurisdictions should be required to report suspicions of child abuse and neglect. Part A will examine some of the American legislative provisions on mandatory reporting that have attempted to include or omit lawyers from the obligation to report. Part B will suggest the proposed amendment and Part $\mathrm{C}$ will offer further general recommendations.

\section{A Problems with Vagueness in Other Jurisdictions}

Many of the problems in the American states that require lawyers to report arise because of the vagueness of the legislation. ${ }^{74}$ Some American states require all people to report child abuse; some specifically mention lawyers but not privilege; and some note that privilege will not relieve a person of their obligation to report. ${ }^{75}$ For example, in Florida 'any person' is required to report, but the statute does not mention privilege of any kind. ${ }^{76}$ In Idaho, any person who has reason to believe a child has been abused must report it. The Act specifically mentions that confessions to a religious minister do not have to be reported but does not mention lawyer-client privilege. ${ }^{77}$ In Oklahoma, every person who has reason to believe a child has been abused or neglected must make a report. The Act clearly states that ' $[\mathrm{n}] \mathrm{o}$ privilege or contract shall relieve any person from the requirement of reporting pursuant to this section,78 and this would appear to include lawyer-client privilege. In Nevada, lawyers are listed as a profession who must report child abuse or neglect. ${ }^{79}$ However, this is subject to $\$ 432 \mathrm{~B} .225$ which prohibits lawyers from reporting abuse when they have obtained the knowledge from privileged communications and the client is either the abuser or the victim. The Nevada provision goes on to say that except for in the above mentioned circumstances, a lawyer must report and also must still comply 'with any ethical duties of attorneys as set forth in the Nevada Rules of Professional Conduct. ${ }^{80}$ It is not clear in exactly what

74 Ellen Marrus, 'Please Keep My Secret: Child Abuse Reporting Statutes, Confidentiality and Juvenile Delinquency’ (1998) 11(3) Georgetown Journal of Legal Ethics 509, 516-9; Lockie, above n 42, 139 .

75 Lockie, above n 42, 126-8.

76 Fla Stat $\$ 39.201(2016)$.

77 Idaho Code Ann $\$ 1605$ (2014).

78 Okla Stat $\$ 7103$ (2006).

79 Nev Rev Stat $\$ 432 B .220$ (2005).

$80 \quad$ Nev Rev Stat $\$ 432 B .225$ (2005). 
situations a lawyer would need to report and in what situations they would be prohibited from reporting.

In Australia, the Northern Territory legislation requires all persons to report child abuse or neglect. The Act states that the 'section has effect despite any other provision in this Act or another law of the Territory. ${ }^{81}$ With some interpretation it can be assumed that this overrules lawyer-client privilege ${ }^{82}$ but it is still somewhat unclear. Avoiding the 'vagueness' evident in other statutes and ensuring that the legislation is clear would mean that lawyers would understand their obligations and result in more positive outcomes for children.

\section{B The Proposed Amendment}

It is recommended that the legislation clearly references solicitors and barristers, and also provides that the legislation overrides legal privilege and confidentiality. If the state or territory's mandatory reporting legislation lists professions that are required to report, the words 'solicitor, barrister or any other member of the legal profession' should be added. As discussed in Part IV, which argued that an exception should be made in cases of domestic violence, these provisions should also include a similarly worded exception to that found in s 327(2) of the Crimes Act 1958 (VIC) where a 'reasonable excuse for not disclosing the information' exists. A section which makes it clear that privilege and confidentiality will not relieve a lawyer of their obligation to report should be added. This section should read:

a) To avoid doubt, the obligation to report under this section applies without exception to any communications which may otherwise be privileged, including information covered by lawyer-client privilege.

b) The obligation to report under this section applies without exception to any communications which may otherwise be confidential.

c) This section has effect despite any other law of the State [or Territory].

Below are some practical examples of how the proposed amendment is intended to apply.

81 Care and Protection of Children Act 2007 (NT) s 26 (3).

82 Bradshaw, above n 19, 6 [18]-[23]. 
If a client says that they have been reported and are being investigated, then a report would be unnecessary. If a lawyer was representing a client in a family law matter and abuse or neglect had been alleged by either party to the court, a report would be unnecessary. If a lawyer was representing a client in a criminal case of child abuse or neglect, a report is clearly unnecessary. In each of these cases legal professional privilege and confidentiality would remain wholly intact.

If a client was seeking advice on an unrelated matter and mentioned that they believed their partner was abusing their children, and no one else had been notified or made a report, the lawyer would be required to make a report. If a client was seeking advice on an unrelated matter and admitted to a lawyer that they had been abusing their children and no one else had been notified or made a report, then a lawyer would need to make a report. If a lawyer was representing a client in a family law matter and the client knew their partner was abusing the children but did not want to raise it in case in could not be proven and they were worried of the real or perceived implications to them in the family court proceedings, the lawyer would need to make a report. If a lawyer was representing a client and became aware that a child was being exposed to domestic violence, the lawyer would be required to make a report - provided it was safe to do so. If the report itself would endanger either the client or their child, the lawyer could rely on the exception to reporting and wait until it was safe to report.

In these cases, for the limited situation of making the report to the relevant authority, privilege or confidentiality would not relieve a lawyer of their duty to report. Only the information required to make the report would be given and all other information and communications would remain privileged and confidential. The level of knowledge required of the lawyer to make the report will differ across each jurisdiction according to the relevant child protection legislation. For example, in South Australia, lawyers would need to suspect on reasonable grounds that a child was being abused or neglected, ${ }^{83}$ while in Tasmania the threshold is 'believes, or suspects, on reasonable grounds, or knows. ${ }^{84}$ The lawyer would need to comply with all relevant definitions under the child protection legislation in their jurisdiction.

83 Children's Protection Act 1993 (SA) s 11.

84 Children, Young Persons and Their Families Act 1997 (Tas) s 14(2). 


\section{Other General Recommendations}

Lawyers should take all necessary steps to minimise any damage to the lawyerclient relationship and when making a report disclose only client information that is required by law for the report. It is further recommended that lawyers receive mandatory reporting training to ensure that they know how to identify child abuse and neglect effectively and know what scenarios justify a report. This will also enable lawyers to distinguish between a client's real concerns for children's welfare and the potential misuse of alleging abuse, for example, as a tactic in a trial. It is also recommended that there be continued discussion in the area of child protection and continued efforts to ensure that those in the legal profession work closely with child protection authorities.

\section{CONCLUSION}

This article has argued that mandatory reporting legislation should be changed to require lawyers to report child abuse and neglect. Mandatory reporting laws protect vulnerable children who are unable to protect themselves. However, lawyers are currently prevented from reporting because of legal privilege and confidentiality. Legal privilege and confidentiality are required to resolve legal disputes and it is in the public interest to resolve those disputes. However, when these concerns are weighed against the public interest in protecting children, the rights of children should prevail. The lawyer-client relationship will not be unduly harmed by requiring lawyers to report suspicions of abuse or neglect. Furthermore, harm to the lawyer-client relationship is preferable to the harm done to a child who is left in a potentially abusive situation. There should be an exception to reporting in cases where the client is a victim of domestic violence, which would protect the victim and also the children from potential further harm. Requiring lawyers to report child abuse and neglect will ensure the protection of the vulnerable and contribute to a safer society for children. 